\title{
Helminths and lipid peroxidation in Astyanax aeneus (Pisces: Characidae) from a river in the humid subtropics of southeastern Mexico
}

\author{
Tania Espinal-Carrión, Eugenia López-López*
}

\begin{abstract}
Laboratorio de Ictiología y Limnología, Departamento de Zoología, Escuela Nacional de Ciencias Biológicas, Instituto Politécnico Nacional, Prol. De Carpio y Plan de Ayala s/n, Col. Santo Tomás, Deleg. Miguel Hidalgo, CP 11340, México DF, Mexico
\end{abstract}

\begin{abstract}
Xenobiotic mixtures in aquatic ecosystems may compromise fish health by inducing oxidative stress, decreasing resistance, and fostering susceptibility to pathogens such as helminths. Lipid peroxidation (LPO) is one of the most commonly used methods to evaluate oxidative stress. The present study examines the potential correlations between LPO in liver, muscle, and gill and the presence of helminths in Astyanax aeneus from a subtropical river in Mexico. Five helminth species were identified: the trematodes Uvulifer ambloplitis, a subdermal larval parasite, and Clinostomum complanatum, which infected the base of the gills; the nematodes Contracaecum sp. and Spiroxys sp.; and the acanthocephalan Polymorphus sp. The latter 3 species occurred in the posterior half of the intestine. Total helminth abundance was highest in April and July. Helminth species richness increased along a gradient from the headwaters to the middle reaches of the river. An integrated biomarker response for LPO (IBR-LPO) was assessed in the 3 tissues analyzed. IBR-LPO peaked in July. A direct correlation was found between gill and muscle LPO and mean abundance of Clinostomum complanatum, Contracaecum sp., and orthophosphate values, as well as between liver LPO and mean abundance of Polymorphus sp., whereas no relationship was found between LPO and $U$. ambloplitis or Spiroxys sp. This research revealed an association of both orthophosphate values and the presence or abundance of parasites with oxidative stress levels in A. aeneus, without any causal association, but rather as a result of synergistic processes associated with these variables.
\end{abstract}

KEY WORDS: Helminths - Lipid peroxidation - Environmental disturbance · Astyanax aeneus . Humid subtropics

Resale or republication not permitted without written consent of the publisher

\section{INTRODUCTION}

Adverse environmental conditions may cause numerous diseases in all types of organisms. In aquatic ecosystems, xenobiotics can compromise fish health through different mechanisms including environmental stress, which can result in pathologies and stimulate the pathogenicity of certain biostressors (Lafferty \& Holt 2003) such as helminths. These pathologies may be caused by adverse effects of poor water quality (e.g. changes in biological oxygen demand, nitrogen and phosphorus levels, salinity, temperature), which produce a significant increase in stress and reduced re- sistance in the host. The limnological, geographic, and trophic characteristics of water systems are additional determinants of both fish health and the structure of fish parasite communities (Hogue \& Swig 2007).

In recent decades, efforts have focused on quantifying the changes in and damage to aquatic biota due to stress resulting from environmental alterations in the aquatic ecosystem (López-López et al. 2006, Tejeda-Vera et al. 2007). One such case is that of oxidative stress, which occurs through disruption of the balance between reactive oxygen species (ROS) and antioxidant defenses. Oxidative stress damages biomolecules such as lipids and induces various physi- 
ological and biochemical changes which cause cell impairment and death (Sherry 2003, Van der Oost et al. 2003). ROS convert fatty acids into fatty acid radicals that are able to oxidize adjacent molecules. This process, known as lipid peroxidation (LPO), yields a large number of subproducts including malondialdehyde (MDA), which, determined in tissues, is used to evaluate oxidative stress (Van der Oost et al. 2003). An increase in ROS levels that the antioxidant defense system is unable to offset may induce major functional changes, compromising the functioning of the immune system and increasing the susceptibility to pathogens such as helminths (Romano 1999). The relationship between oxidative stress and the presence of parasites has scarcely been studied in fish (Belló et al. 2000) and is even less well known for fish from tropical ecosystems. Thus, the aim of the present study was to examine the potential correlations between parasites of the banded tetra Astyanax aeneus (Günther, 1860) and LPO levels in the liver, muscle, and gill of the fish, as well as to assess water quality indicators in the Río Champotón in southeastern Mexico.

\section{MATERIALS AND METHODS}

Fish specimens were collected from the Río Champotón in the humid subtropics $\left(19^{\circ} 24^{\prime} 00^{\prime \prime}\right.$ to $19^{\circ} 05^{\prime} 24^{\prime \prime} \mathrm{N}, 90^{\circ} 43^{\prime} 12^{\prime \prime}$ to $90^{\circ} 23^{\prime} 24^{\prime \prime} \mathrm{W}$ ) of southeastern Mexico. Río Champotón has 2 zones: the freshwater zone, with salinity values $<1.2$ (PSU); and the estuarine zone, where salinity wedges occurred and salinity values range from 10 to 35 (PSU), except in the hurricane season, when salinity depletes to freshwater conditions. Astyanax aeneus is a primary freshwater fish that is intolerant to saltwater (Myers 1949). Fish were collected only in the freshwater zone of Río Champotón, in the upper and middle reaches (LópezLópez et al. 2009). Four sampling seasons were con- ducted in the course of 1 yr: spring (April 27 to 29, 2007), summer (July 22 to 26, 2007), fall (November 7 to 13,2007 ), and winter (February 21 to 25, 2008) at 4 study sites (Fig. 1): San Juan Carpizo (SJC), Santa Sara (SS), San Antonio del Río (SAR), and Puente Ulumal (PU). A minimum of 200 specimens ranging in size from 45 to $85 \mathrm{~mm}$ standard mean length were collected at each site during each sampling season. Of these, 25 were used in the parasite analysis and the rest were dissected to obtain liver, muscle, and gill tissue for LPO determination. Since at least $1 \mathrm{~g}$ of each tissue is required for biochemical assays and $A$. aeneus is a very small species (52.38 mm standard mean length, $5.91 \mathrm{~g}$ mean weight), the assays were made on 4 pools of 50 organs. Dissected organs were transported to the laboratory in liquid nitrogen for processing.

Fish specimens were necropsied microscopically for ecto- and endoparasites. Parasites were counted and sorted by taxon for appropriate fixing and preservation. Taxonomic keys were used to identify the parasites (Caspeta-Mandujano 2005, Salgado-Maldonado 2006). Infection was characterized in terms of helminth mean abundance according to Bush et al. (1997). Sample size to analyze helminth infection was determinate according to cumulative curves.

Anthropogenic activities such as agriculture, aquaculture, and human settlement in areas adjacent to the sampling sites were regarded as indicators of environmental disturbance. Water samples were collected to determine $\mathrm{N}$ (nitrite, nitrate, ammonium) and $\mathrm{P}$ (orthophosphate) using a HACH Model DLR/2500 spectrophotometer, while biological oxygen demand over $5 \mathrm{~d}\left(\mathrm{BOD}_{5}\right)$ and total and fecal coliforms were quantified according to APHA (1985) procedures. Dissolved oxygen, salinity, and temperature were measured in situ using a Quanta multiparametric sonde.

LPO was determined in each tissue using the method of Buege \& Aust (1978) on homogenates from the pools of the organs under study, previously rinsed in Tris-

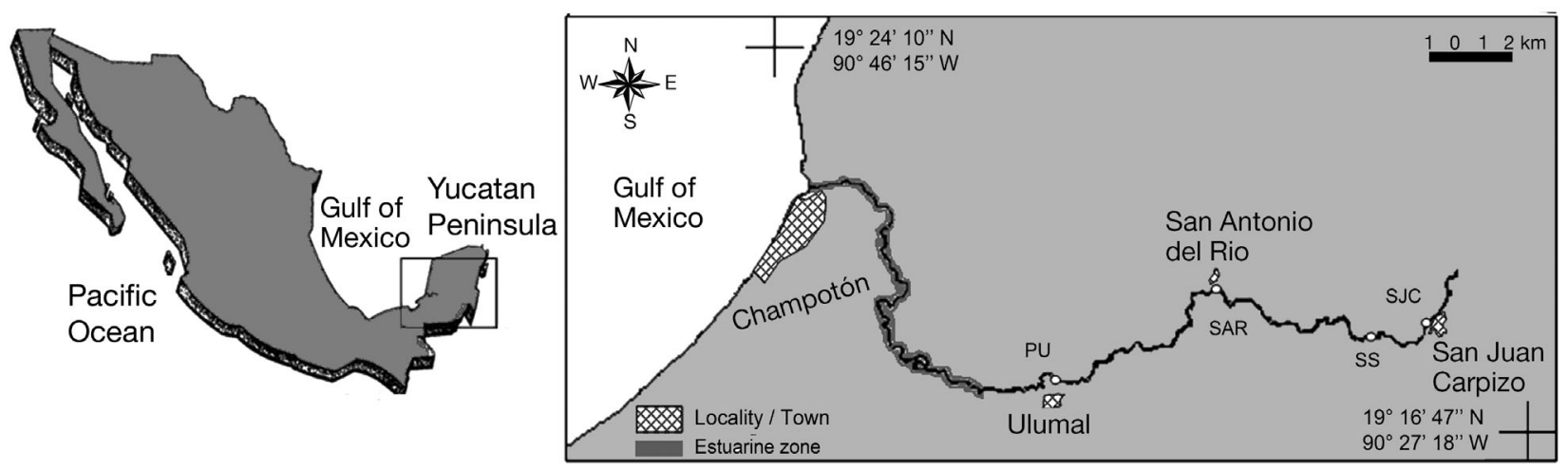

Fig. 1. Study area and study sites. PU: Puente Ulumal; SAR: San Antonio del Río; SJC: San Juan Carpizo; SS: Santa Sara 
HCl buffer ( $\mathrm{pH}$ 7.4). The MDA produced was quantified. Protein content was determined by the Bradford (1976) method.

LPO data were normalized and standardized. Values from assays of the pooled sample of each tissue (liver, muscle, and gill) from each study site were used as $x$. The overall mean and standard deviation (SD) of the $x$ values of each tissue were calculated for all study sites and sampling seasons and normalized as $y=(x-$ mean)/SD. The minimum absolute value (min.) of the $y$ values of each tissue from all study sites and sampling seasons was added to the $y$ values to standardize LPO data: $y+(\min$.$) .$

The integrated biomarker response (IBR) was estimated using the procedure proposed by Beliaeff \& Burgeot (2002). In the present study, IBR represents the integrated LPO response in liver, muscle, and gill (IBR-LPO) by site and sampling season. Results are shown in the form of star plots for each site and sampling season. Each vector represents liver, muscle, or gill LPO. The area enclosed by the triangle connecting the endpoints of vectors represents the IBR-LPO.

A Spearman correlation analysis was performed using the LPO values for each tissue, study site, and sampling season, IBR-LPO, environmental factors, species richness and mean abundance of each helminth species, and total helminth abundance. The level of significance was set at $\mathrm{p}=0.05$.

A redundancy analysis (RDA) was conducted using the LPO for each tissue, helminth mean abundance and water quality parameters in each site and sampling season. To this end, a matrix of environmental factors and LPO in each tissue by site was set up using standardized data $(\log x+1)$. Statistical analyses were performed with XLSTAT-Pro 2008.6 software.

\section{RESULTS}

\section{Helminths}

The component community of helminths in Astyanax aeneus was found to be formed by the following 5 species (Table 1): Uvulifer ambloplitis (Hughes, 1927) and Clinostomum complanatum (Rudolphi, 1814) (Trematoda); Contracaecum sp. (Railliet and Henry, 1912) and Spiroxys sp. (Schneider, 1866) (Nematoda); and Polymorphus sp. (Lühe, 1911) (Acanthocephala). These species differed in their distribution in the body of the host. Only 1 species was found infecting the skin: $U$. ambloplitis. Clinostomum complanatum was found only at the base of the gill arches. The remaining species occurred in the posterior half of the intestine.

Helminth species richness present in Astyanax aeneus increased from the upper reaches (Site SJC), where only 2 species were recorded, to the middle reaches (Site PU) where 5 species were found (Table 2). Contracaecum sp. and Spiroxys sp. were present at all sites, while Uvulifer ambloplitis and Polymorphus sp. occurred only in the middle reaches (Sites SAR and PU). Clinostomum complanatum was found at 2 sites, in the upper (Site SS) and middle reaches (Site PU). July had the highest species richness with 4 species, while April, November, and February had the lowest (Table 1).

By site and sampling season, Astyanax aeneus was host to a maximum of 4 helminth species at Site PU in July. Helminth species richness per site was usually $<2$ (Table 1). No helminths were found at Site SS in April and at Site SJC in November and February.

Helminth mean abundances were low. Peak values occurred in July and April (16.54 \pm 6.69 and 5.6 \pm 2.5, respectively). November and February had the lowest

Table 1. Helminths infecting Astyanax aenus. Mean \pm SD abundance and number of helminth species in fish by site and sampling season. PU: Puente Ulumal; SAR: San Antonio del Río; SJC: San Juan Carpizo; SS: Santa Sara

\begin{tabular}{|c|c|c|c|c|c|c|c|c|}
\hline Month & Site & $\begin{array}{c}\text { Contracaecum } \\
\text { sp. }\end{array}$ & $\begin{array}{l}\text { Spiroxys } \\
\text { sp. }\end{array}$ & $\begin{array}{c}\text { Uvulifer } \\
\text { ambloplitis }\end{array}$ & $\begin{array}{l}\text { Clinostomum } \\
\text { complanatum }\end{array}$ & $\begin{array}{l}\text { Polymorphus } \\
\text { sp. }\end{array}$ & $\begin{array}{l}\text { Species } \\
\text { richness }\end{array}$ & $\begin{array}{c}\text { Total } \\
\text { abundance }\end{array}$ \\
\hline \multirow[t]{4}{*}{ Apr } & SJC & 0 & $0.10 \pm 0.31$ & 0 & 0 & 0 & 1 & $0.10 \pm 0.04$ \\
\hline & SS & 0 & 0 & 0 & 0 & 0 & 0 & 0 \\
\hline & SAR & 0 & $0.30 \pm 0.65$ & 0 & 0 & 0 & 1 & $0.30 \pm 0.13$ \\
\hline & PU & 0 & 0 & $5.2 \pm 10.8$ & 0 & 0 & 1 & $5.20 \pm 2.33$ \\
\hline \multirow[t]{4}{*}{ Jul } & SJC & $0.10 \pm 0.28$ & 0 & 0 & 0 & 0 & 1 & $0.10 \pm 0.04$ \\
\hline & SS & $0.20 \pm 0.37$ & $0.10 \pm 0.28$ & 0 & $0.20 \pm 0.37$ & 0 & 3 & $0.50 \pm 0.10$ \\
\hline & SAR & $0.05 \pm 0.22$ & 0 & $1.7 \pm 7.60$ & 0 & 0 & 1 & $2.70 \pm 0.76$ \\
\hline & PU & $0.10 \pm 0.40$ & $0.04 \pm 0.20$ & $13 \pm 16$ & $0.10 \pm 0.28$ & 0 & 4 & $13.24 \pm 5.79$ \\
\hline \multirow[t]{3}{*}{ Nov } & SJC & 0 & 0 & 0 & 0 & 0 & 0 & 0 \\
\hline & SAR & $0.10 \pm 0.20$ & 0 & 0 & 0 & $0.10 \pm 0.20$ & 2 & $0.20 \pm 0.05$ \\
\hline & PU & 0 & 0 & 0 & 0 & $0.04 \pm 0.20$ & 1 & $0.04 \pm 0.02$ \\
\hline \multirow[t]{4}{*}{ Feb } & SJC & $0.10 \pm 0.20$ & $0.20 \pm 0.44$ & 0 & 0 & 0 & 2 & $0.30 \pm 0.09$ \\
\hline & SS & $0.40 \pm 0.86$ & $0.04 \pm 0.20$ & 0 & 0 & 0 & 2 & $0.44 \pm 0.18$ \\
\hline & SAR & $0.30 \pm 0.41$ & 0 & 0 & 0 & 0 & 1 & $0.30 \pm 0.13$ \\
\hline & PU & 0 & 0 & 0 & 0 & 0 & 0 & 0 \\
\hline
\end{tabular}


Table 2. Helminths infecting Astyanax aenus. Spatial and seasonal distribution of helminth species in fish by site and sampling season. PU: Puente Ulumal; SAR: San Antonio del Río; SJC: San Juan Carpizo; SS: Santa Sara

\begin{tabular}{|c|c|c|c|c|c|c|c|c|}
\hline \multirow{2}{*}{ Species } & \multirow[b]{2}{*}{ SJC } & \multirow{2}{*}{ SS } & \multirow[b]{2}{*}{ SAR } & \multirow[b]{2}{*}{ PU } & \multirow{2}{*}{ Apr } & \multirow[b]{2}{*}{ Jul } & \multirow{2}{*}{$\mathrm{Nov}$} & \multirow[b]{2}{*}{ Feb } \\
\hline & & & & & & & & \\
\hline Contracaecum sp. & $\mathrm{X}$ & $\mathrm{X}$ & $\mathrm{X}$ & $\mathrm{X}$ & & $\mathrm{X}$ & $\mathrm{X}$ & $\mathrm{X}$ \\
\hline Spiroxys sp. & $\mathrm{X}$ & $\mathrm{X}$ & $\mathrm{X}$ & $\mathrm{X}$ & & $\mathrm{X}$ & & $\mathrm{X}$ \\
\hline Uvulifer ambloplitis & & & $\mathrm{X}$ & $\mathrm{X}$ & $\mathrm{X}$ & $\mathrm{X}$ & & \\
\hline Clinostomum complanatum & & $\mathrm{X}$ & & $\mathrm{X}$ & $\mathrm{X}$ & $\mathrm{X}$ & & \\
\hline Polymorphus sp. & & & $\mathrm{X}$ & $\mathrm{X}$ & & & $\mathrm{X}$ & \\
\hline No. of species & 2 & 3 & 4 & 5 & 2 & 4 & 2 & 2 \\
\hline
\end{tabular}

mean abundances (Table 2). Uvulifer ambloplitis had the highest mean abundances, although this only occurred in July, when maximum mean abundances were reached, and in April, when it was found only at Site PU. Contracaecum sp. had its maximum mean abundance in February, when it was present at all sites except Site PU. Spiroxys sp. was most abundant at Site SAR in April but occurred at all other sites in every sampling season, although with lower values, except in November. Clinostomum complanatum was found only at Sites SS and PU in July and Polymorphus sp. only at Sites SAR and PU in November.

\section{Habitat characteristics}

Water temperature remained constant throughout the year and between sites. Salinity showed values $<1.2$ PSU (range, 0.11 to 1.19 PSU), with slight variation between sites, but in November had a marked depletion to values $<0.2$ PSU due to the rains and hurricanes which caused severe freshwater flooding.

Water quality parameters differed between study sites and sampling seasons (Fig. 2). Dissolved oxygen was highest at Sites SAR and PU, particularly in November. Ammonium and nitrite levels were low $\left(<0.1\right.$ and $<0.01 \mathrm{mg} \mathrm{l}^{-1}$, respectively). Sites SJC and SS had the highest levels of ammonium and nitrate, respectively, while orthophosphate was highest at Sites SAR and PU. Mean values of BOD $_{5}$ were similar at all study sites. The maximum numbers of fecal and total coliforms occurred at Site SS and the minimum at Site SJC (Fig. 2A). Ammonium levels peaked in November and February. The highest levels of nitrate occurred in July. Nutrient concentrations ( $\mathrm{N}$ and $\mathrm{P}$ ) were highest in July and lowest in November. BOD 5 peaked in April and was lowest in November. Maximum fecal and total coliforms occurred in July. Based on these results, we can say that the upper reaches of the river (Sites SJC and SS) have higher levels of nitrogen compounds, while the middle reaches (Sites SAR and PU) are high in ortophosphate and organic matter.

\section{LPO}

LPO in Astyanax aeneus differed between sites as well as between sampling seasons and tissues (Fig. 3). The star plots show that IBR-LPO was highest in July (total IBR, 12.23) and April (total IBR, 12.09). In April, Sites SJC and SAR had the highest levels of liver, muscle, and gill LPO, while in July the highest LPO values were found at Sites PU and SS. November and February were low in oxidative stress. Total IBR was highest at Sites SAR and SJC (15.0 and 10.15, respectively). The vector for gill LPO had the highest values in all sites and sampling seasons followed by the one for liver LPO, suggesting these are the organs most affected by oxidative stress.

\section{Relationships between LPO, helminths, and environ- mental factors}

Spearman correlation analysis of the LPO by organ, IBR-LPO, environmental factors, and helminth mean abundance and species richness indicated that Clinostomum complanatum was directly correlated with orthophosphate and gill and muscle LPO, with correlation coefficients of $0.538,0.550$, and 0.592 , respectively ( $\mathrm{p}=0.05$ ) (Table 3). Polymorphus sp. was directly correlated with liver LPO and dissolved oxygen (correlation coefficient, 0.592; $\mathrm{p}=0.05$ ). No relationship was seen between Spiroxys sp. and LPO in a specific tissue, but this species was directly correlated with $\mathrm{BOD}_{5}$ and IBR-LPO. Contracaecum sp. and Uvulifer ambloplitis were not associated with LPO or environmental factors, but were directly correlated with the number of helminth species, and $U$. ambloplitis in particular with total helminth abundance.

RDA comprising LPO by tissue, helminth mean abundance, and environmental factors at each study site produced a biplot in which the first 2 components accounted for $98.27 \%$ of the explained variance (Fig. 4). A close correlation was found between gill LPO, mean abundance of Contracaecum sp. and Cli- 

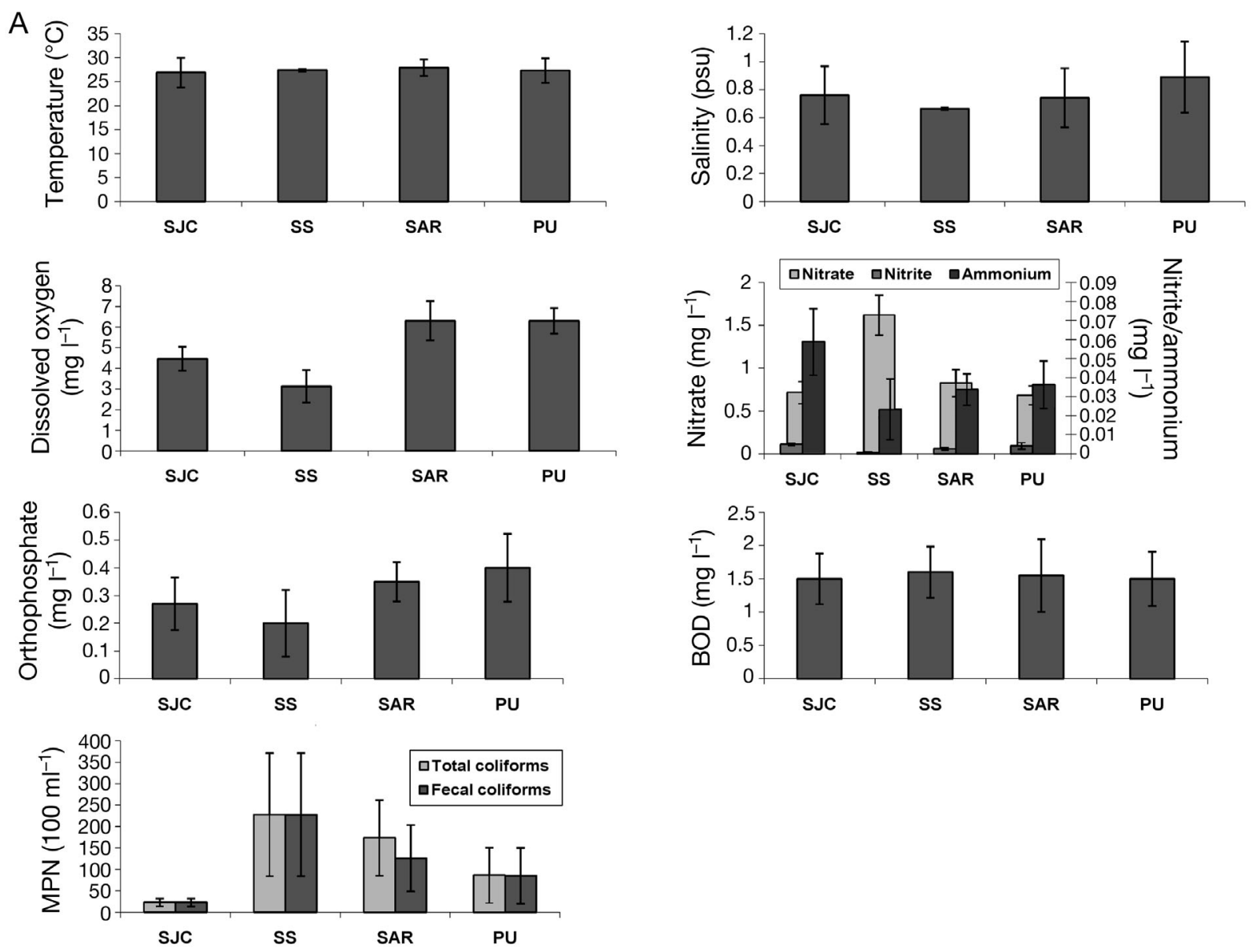

Fig. 2 (above and next page). Mean $( \pm \mathrm{SD}$ ) values of water quality parameters by (A) site (PU: Puente Ulumal; SAR: San Antonio del Río; SJC: San Juan Carpizo; SS: Santa Sara) and (B) sampling season (A: April 27 to 29, 2007; J: July 22 to 26, 2007 ; N: November 7 to 13, 2007; F: February 21 to 25, 2008). BOD: biological oxygen demand; MPN: more probable number

nostomum complanatum, maximum coliforms, and peak levels of orthophosphate, which occurred concurrently in July at Sites PU, SAR, and SS. Uvulifer ambloplitis, the most abundant helminth, and Spiroxys sp. had the lowest correlation coefficients with LPO, but were directly correlated with fecal coliforms and $\mathrm{BOD}_{5}$, respectively. Liver LPO was also associated with dissolved oxygen, nitrite, and ammonium at all study sites in November. RDA showed the existence of seasonal differences in the component community of helminths in Astyanax aeneus as well as their relationship with water quality parameters, and also indicates that some helminth species are associated with oxidative stress.

\section{DISCUSSION}

Water quality parameters support the existence of some amount of environmental disturbance along the river course. Sites in the upper reaches (Sites SJC and SS), characterized by low agricultural activity, very small human settlements, and cattle breeding with watering areas, are high in nitrogen compounds, particularly nitrate. This is probably due to fertilizer inputs and the breakdown of untreated animal and human waste by microorganisms, as suggested by the high numbers of fecal coliforms in this area. These sites were also low in organic matter, perhaps due to continuous mineralization, which in turn indicates that this area is not highly contaminated. Sites in the middle reaches (Sites SAR and PU) are nutrient-rich and have higher levels of organic matter, probably due to the presence of larger human settlements and the use of Site SAR as a swimming spot and camping area. High levels of nutrients and organic matter at Site PU are more probably due to farming of tilapia in floating cages. Both areas are therefore undergoing eutrophication. However, based on water quality parameters as well as nitrogen levels (Camargo \& Alonso 2006), the 

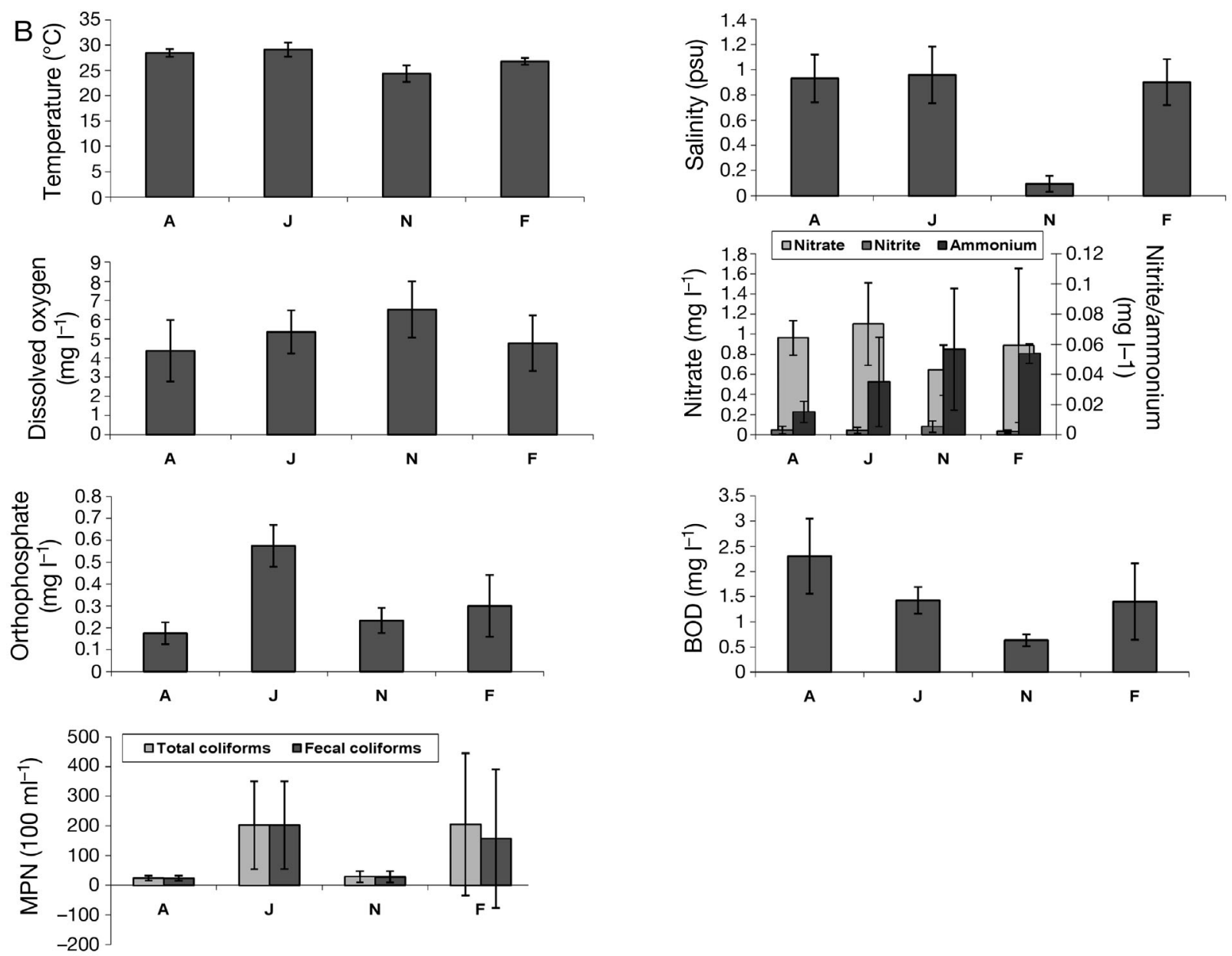

Fig. 2 (continued)

Río Champotón sustains low environmental degradation in spite of the activities taking place along its course. Total and fecal coliforms at all sites were below the maximum numbers allowed for effluents by Mexican legislation (NOM 2006).

Environmental stress is a major factor in the incidence and abundance of helminths, since it may increase the prevalence of certain biostressors (Marcogliese \& Cone 1997). However, wild animals in systems with environmental disturbance may be subject both to an increased risk of parasitosis (Mancini et al. 2000) and a decreased risk of endoparasitical infections, while sustaining more ectoparasites (Silva et al. 2005). On the other hand, nematode abundance is higher in fish living in systems contaminated with domestic waste and industrial discharges than in those from lower impact areas (Olivero-Verbel et al. 2005). Our results show that helminth species richness and mean abundances are higher in the middle reaches where human settlements are larger, and also where eutrophication was detected. Also, the most abundant helminth species occurred only in this part of the river. Helminth mean abundances are much lower in the Champotón than in the Papaloapan and Ayuquila rivers (Salgado-Maldonado et al. 2004, 2005). This suggests there is less environmental disturbance in the Río Champotón than in either of these 2 rivers, although a tendency toward eutrophication was observed in the Champotón River.

Transmission and distribution of helminths could be related to historical and contemporary events. Among contemporary events, seasonal variations in rainfall pattern can favor changes in the structure of fish populations and communities, as well as in plants and invertebrates that serve as intermediary hosts (Vidal-Martínez et al. 2002). During November, because it was hurricane season, a depletion of salinity was observed in the estuarine zone, allowing migration of Astyanax aeneus to this zone. However, during the rest of the year, $A$. aeneus had a migratory pattern which seemed to be associated with the amount of food available to the bigger fish at Site PU (Jamett-Mora et al. 1996). Also during Novem- 

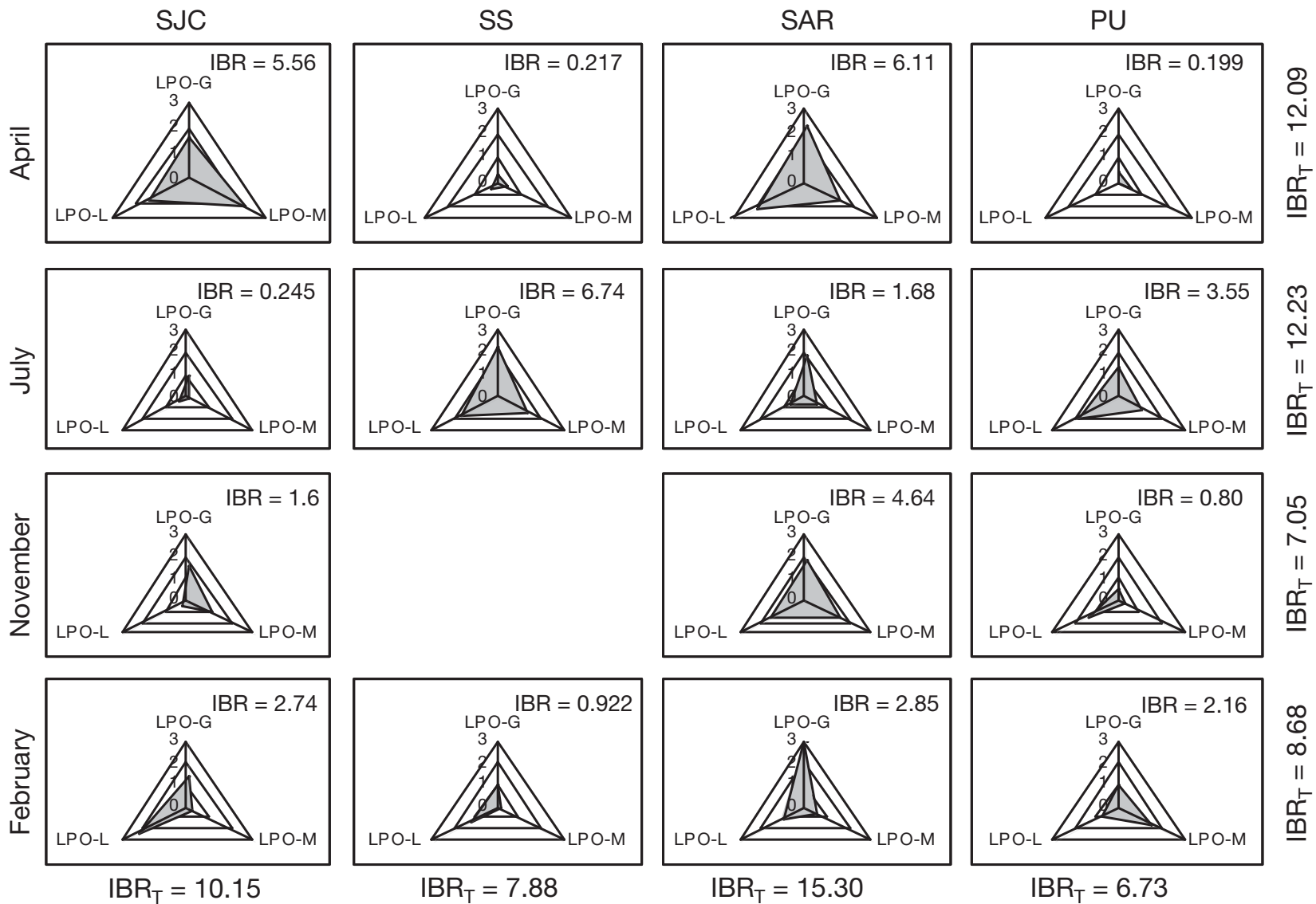

Fig. 3. Star plots of the integrated biomarker response (IBR) for lipid peroxidation (LPO). Shaded area represents the IBR. Vectors represent LPO in gill (LPO-G), muscle (LPO-M), and liver (LPO-L) of Astyanax aeneus. The numbers 0 to 3 indicate the dimensionless scale of the IBR. PU: Puente Ulumal; SAR: San Antonio del Río; SJC: San Juan Carpizo; SS: Santa Sara. IBRT: total IBR. It was not possible to access Site SS in November (hurricane season)

ber, with the depletion in salinity there was an increase in species richness of fish in the middle reaches and estuarine zone of the river Champotón caused by the entry of marine species in these areas (López-López et al. 2009); this event provoked an interaction between the freshwater species with estuarine and marine fish. This interaction allowed some parasites such as Polymorphus sp., a common generalistic marine fish helminth (Tantaleán et al. 2005), to parasitize A. aeneus. However, November showed the lowest helminth richness and abundance, suggesting that in this month an intermediary host could also have been affected by the severe flooding of the river, and life cycles of helminths could not be completed on a regular basis.

As for historical events, Pérez-Ponce de León \& Choudhury (2005) consider that the parasite fauna is largely circumscribed by higher levels of monophyletic host taxa (families, orders, etc.), and that this pattern is independent of areas. The same authors found that the pattern of host associations in each of the drainages indicates that, for most of the fish families, the para- sites are largely restricted to the level of host family, with low levels of parasite exchange (with very few exceptions). Sharing of parasites is also mainly restricted to species within a monophyletic lineage of hosts (confamilial hosts for most parasites, ordinal level for some). Ornelas-García et al. (2008) consider that Astyanax spp. in North America and upper Central America form a monophyletic group. This could explain the low species richness of helminths found in A. aeneus in Champotón versus the high richness of fish-fauna in the river and in a zone where only one species of Astyanax was found.

All worms in the present study were found in larval stages, and there were differences in their spatial and seasonal distribution. Contracaecum sp. and Spiroxys sp. showed the widest spatial distribution as they were recorded at all study sites, while Uvulifer ambloplitis, Polymorphus sp., and Clinostomum complanatum were found at specific sites (the first 2 at Sites SAR and PU and the third at Sites SS and PU). Likewise, their seasonal distribution varied. The most con- 


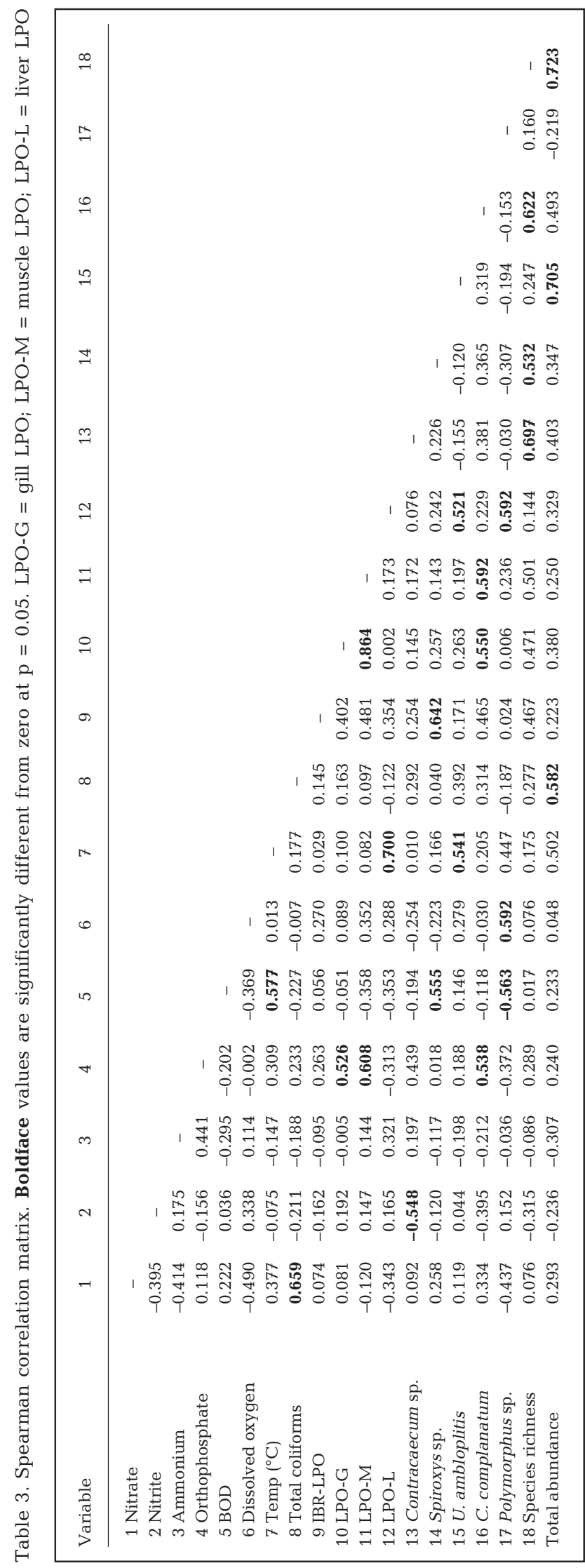

spicuous case was Polymorphus sp., which was recorded only in November. These differences may be because all helminths we found are allogenic species, and so they need intermediary hosts, mainly mollusks (snails), as well as definitive hosts (piscivorous birds) to complete their life cycle (Vidal-Martínez et al. 2002), which indicates that it is likely that these hosts are not distributed throughout the year nor at all sites. Based on the water quality parameters found in the present study, Champotón River could be considered to be a low impacted river in terms of environmental disturbance. However, Rendón von Osten et al. (2008) reported that small quantities of several persistent (non biodegradable) organic compounds, such as PCBs, DDT, endosulfans, and heptalchlors, were found in the sediments of the Rio Champotón in the main and possibly waning populations of invertebrates that serve as the first intermediate hosts to most of the parasitic helminths (Iannacone et al. 2002). Several persistent pollutants in aquatic systems provoke an increase in oxidative stress (Van der Oost et al. 2003).

LPO is usually higher in fish from contaminated systems than in those from less contaminated areas, irrespective of the type of parasitosis (Marcogliese et al. 2005). In the present study, LPO varied widely between sites, tissue types, and sampling season, but maximum IBR-LPO occurred in July, and gill always had the highest LPO, probably because it is exposed to all disturbances in the aquatic ecosystem (Peña et al. 2001), including lixiviation by agrochemicals used in the adjacent areas of the river. Since the Río Champotón is not highly disturbed, LPO was lower in all tissues than in fish from more contaminated rivers (Marcogliese et al. 2005, López-López et al. 2006, Tejeda-Vera et al. 2007).

Environmental changes may affect fish resistance and increase infection levels (Marcogliese et al. 2005). In turn, the presence of parasites induces higher energy and oxygen consumption in the host fish (Voutilainen et al. 2008), which increases oxidative metabolism (ROS) as well as damage at the cellular membrane level. An increase or decrease in ROS levels can lead to major changes (Sherry 2003) which compromise the function of the immune system through increased susceptibility to pathogens such as parasitic worms (Romano 1999). The results of the present study suggest that mean abundances of Clinostomum complanatum, Contracaecum sp., and Polymorphus sp. are directly correlated with LPO in specific organs. Uvulifer ambloplitis and Spiroxys sp., on the other hand, were not correlated with LPO in the 3 organs and therefore probably infect Astyanax aeneus regardless of the level of oxidative stress. LPO was highest at all sites in July, coinciding with maxi- 


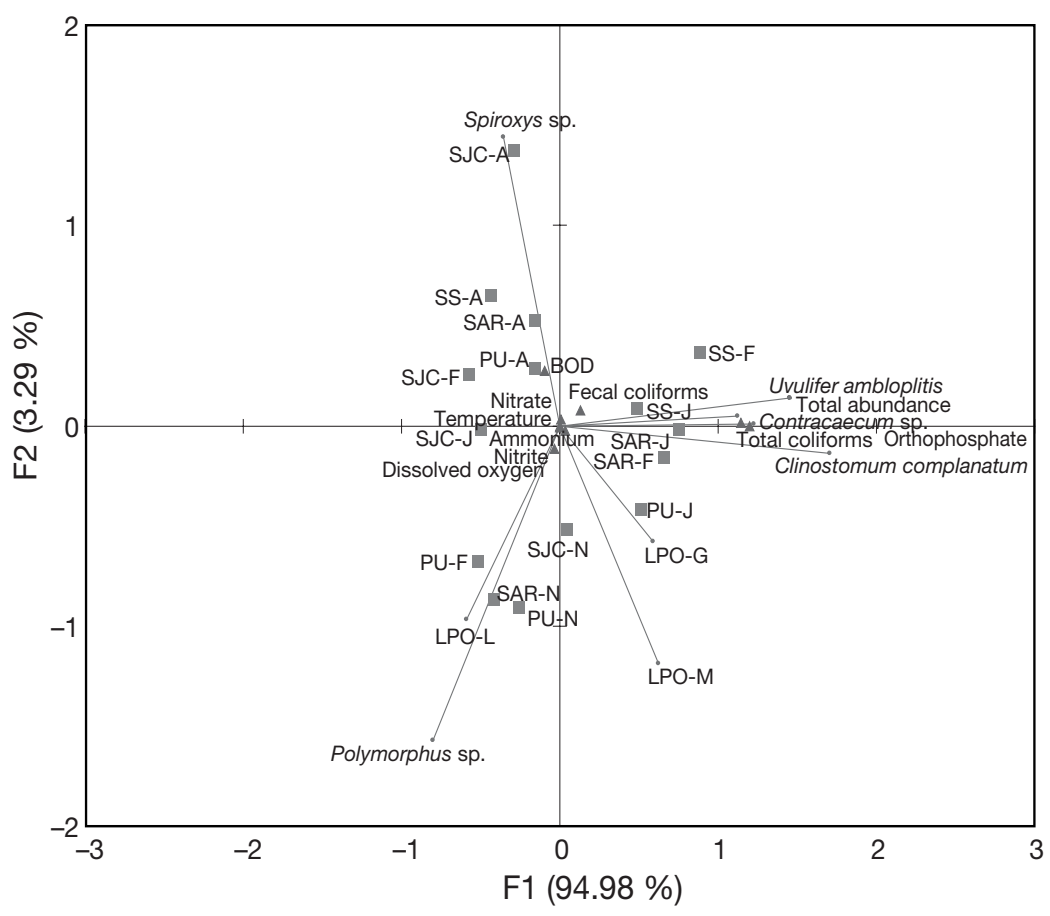

Fig. 4. Redundancy analysis of the study sites based on lipid peroxidation (LPO), water quality parameters, and helminths in Astyanax aeneus. Vectors represent LPO (in gill, LPO-G; muscle, LPO-M; and liver, LPO-L) and helminth mean abundance; squares represent sites (PU: Puente Ulumal; SAR: San Antonio del Río; SJC: San Juan Carpizo; SS: Santa Sara) and sampling seasons (A: April 27 to 29, 2007; J: July 22 to 26, 2007; N: November 7 to 13, 2007; F: February 21 to 25, 2008); triangles represent water quality parameters
LPO induction in fish caused by the presence of Contracaecum sp. or Polymorphus sp. The present study data are thus the first to show a relationship between these helminths and the oxidative status of the liver in Astyanax aeneus, which could be associated with ROS production during inflammatory processes that play an important role in host defense against infections (Eberlein et al. 2008).

The present research revealed an association of both orthophosphates values and the presence or abundance of parasites with oxidative stress levels (LPO) in Astyanax aeneus. This is not a causal association, but rather is the result of synergistic processes associated with these and other variables, since oxidative stress is the result of any process that generates ROS.

Acknowledgements. The present study was financed by the National Science and Technology Council (CONACyT-Mexico) and the government of the state of Campeche (Project 31173), as well as the Secretariat of Research and Postgraduate Studies (SIP) of the National Polytechnic Institute (IPN-Mexico). mum helminth species richness and abundances and with higher orthophosphate concentrations, which may also induce an overall increase in oxidative stress in the fish, as evidenced by the IBR-LPO values.

Few studies have been done on the relationship between LPO and the presence of parasites. However, data about LPO and helminth infections suggest that parasites increase the oxidative status in fish (Belló et al. 2000, Marcogliese et al. 2005). Belló et al. (2000) reported that Clinostomum detruncatum infects the base of the caudal and pectoral fins of the freshwater fish Rhamdia quelem and induces muscle LPO. The data of the present study suggest that something similar occurs in the case of C. complanatum and Astyanax aeneus, since a close correlation was found between mean abundance of the former and muscle LPO in the latter. In the present study, C. complanatum also infected the base of the gill arches and was directly correlated with gill LPO. Marcogliese et al. (2005) found that fish infected with the nematode Raphidascaris acus had higher levels of LPO compared with uninfected fish and that those infected with >10 metacercaria of Apophallus brevis displayed higher levels of LPO. There are no previous records of

\section{LITERATURE CITED}

APHA (American Public Health Association) (1985) Standard methods for the examination of water and wastewater. APHA, AWWA, WPCF, Washington, DC

Beliaeff B, Burgeot T (2002) Integrated biomarker response: a useful tool for ecological risk assessment. Environ Toxicol Chem 21:1316-1322

Belló ARR, Fortes E, Belló-Klein A, Belló AA, Llesuy SF, Robaldo RB, Bianchini A (2000) Lipid peroxidation induced by Clinostomum detruncatum in muscle of the freshwater fish Rhamdia quelem. Dis Aquat Org 42:233-236

Bradford MM (1976) A rapid and sensitive method for the quantitation of microgram quantities of protein utilizing the principle of protein-dye binding. Anal Biochem 72:248-254

Buege JA, Aust SD (1978) Microsomal lipid peroxidation. Methods Enzymol 52:302-307

Bush AO, Lafferty KD, Lotz JM, Shostak AW (1997) Parasitology meets ecology on its own terms: Margolis et al. revisited. J Parasitol 83:575-583

> Camargo JA, Alonso A (2006) Ecological and toxicological effects of inorganic nitrogen pollution in aquatic ecosystems: a global assessment. Environ Int 32:831-849

Caspeta-Mandujano JM (2005) Nematode parasites of freshwater fish in Mexico: key to species, descriptions and distribution. Universidad Autónoma del Estado de Morelos, Cuernavaca

Eberlein M, Scheibner KA, Black KE, Collins SL, Chan-Lee Y, Powell JD, Horton MR (2008) Anti-oxidant inhibition of hyaluronan fragment-induced inflammatory gene expres- 
sion. J Inflamm 5:20

Hogue C, Swig B (2007) Habitat quality and endoparasitism in the Pacific sanddab Citharichthys sordidus from Santa Monica Bay, southern California. J Fish Biol 70:231-242

Iannacone J, Caballero RC, Alvariño FL (2002) Empleo del caracol de agua dulce Physa venustula Gould como herramienta ecotoxicológica para la evaluación de riesgos ambientales por plaguicidas. Agric Tec (Chile) 62:212-225

Jamett-Mora M, Cabrera-Peña J, Alvarado-Bogantes W (1996) Crecimiento y maduración sexual de Astyanax fasciatus (Pises:Characidae) en el embalse Arenal, Guanacaste, Costa Rica. Rev Biol Trop 36:171-172

Lafferty KD, Holt RD (2003) How should environmental stress affect the population dynamic of disease? Ecol Lett 6:654-664

López-López E, Sedeño-Díaz JE, Favari P (2006) Lipid peroxidation and acetylcholinesterase activity as biomarkers in the black sailfin goodeid Girardinichthys viviparous (Bustamante) exposed to water from Lake Xochimilco (Mexico). Aquat Ecosyst Health Manag 9:379-385

López-López E, Sedeño-Díaz JE, López Romero F, TrujilloJiménez P (2009) Spatial and seasonal distribution patterns of fish assemblages in the Río Champotón, southeastern Mexico. Rev Fish Biol Fish:19:127-142

Mancini M, Larriestra A, Sanchez J (2000) Estudio ictiopatológico de poblaciones silvestres de la región centro-sur de Córdoba, Argentina. Rev Med Vet 81:104-108

Marcogliese DJ, Cone DK (1997) Parasite communities as indicators of ecosystem stress. Parassitologia 39:227-232

Marcogliese DJ, Gagnon Brambilla L, Gagne F, Gendron AD (2005) Joint effects of parasitism and pollution on oxidative stress biomarkers in yellow perch Perca flavescens. Dis Aquat Org 63:77-84

Myers GS (1949) Salt tolerance of freshwater fish groups in relation to zoogeographical problems. Bijdr Dierkd 28: 315-322

NOM (Norma Oficial Mexicana) (2006) Mexican official regulation NOM-001-SEMARNAT-1996. Establishing the maximum numbers allowed of pollutants of wastewater discharges into national water. April 23. Secretaría de Medio Ambiente, Recursos Naturales y Pesca, Mexico City

Olivero-Verbel J, Baldiris-Ávila R, Arroyo-Salgado B (2005) Nematode infection in Mugil incilis (Lisa) in Cartagena Bay and Totumo Marsh, north of Colombia. J Parasitol 91:1109-1112

Ornelas-García CP, Domínguez-Domínguez O, Doadrio I (2008) Evolutionary history of the fish genus Astyanax Bair \& Girard (1854) (Actinopterygii, Characidae) in Mesoamerica reveals multiple morphological homoplasies. BMC Evol Biol 8:340

Editorial responsibility: Robin Overstreet, Ocean Springs, Mississippi, USA
Peña CE, Carter DE, Ayala Fierro F (2001) Toxicología ambiental: evaluación de riesgos y restauración ambiental. Southwest Hazardous Waste Program. University of Arizona, Tucson, AZ

Pérez-Ponce de León G, Choudhury A (2005) Biogeography of helminth parasites of freshwater fishes in Mexico: the search for patterns and processes. J Biogeogr 32:645-659

Rendón von Osten J, Flores Hernández D, España Pech LM, Gómez Criollo F, Sosa López A (2008) Contaminantes persistentes en el valle de Yohaltún y el río Champotón, Campeche. Jaina 19:4-10

Romano LA (1999) Bioindicadores de contaminación acuática en peces. Rev Aquat 7, www.revistaaquatic.com/aquatic/ art.asp? $\mathrm{t}=\mathrm{h} \& \mathrm{c}=67$ (accessed July 2008)

Salgado-Maldonado G (2006) Checklist of helminth parasites of freshwater fishes from Mexico. Magnolia Press, Auckland

Salgado-Maldonado G, Mercado-Silva N, Cabañas-Carranza G, Caspeta-Mandujano JM, Aguilar-Aguilar R, IñiguezDávalos LI (2004) Helminth parasites of freshwater fishes of the Ayuquila River, Sierra de Manantlán Biosphere Reserve, west central Mexico. Comp Parasitol 71:67-72

Salgado-Maldonado G, Aguilar-Aguilar R, Cabañas-Carranza G, Soto-Galera E, Mendoza Palmero C (2005) Helminth parasites in freshwater fish from the Papaloapan River basin, Mexico. Parasitol Res 96:69-89

Sherry JP (2003) The role of biomarkers in the health assessment of aquatic ecosystems. Aquat Ecosyst Health Manage 6:423-440

Silva VA, Valenzuela A, Ruíz P, Oyarzun C (2005) Trypanosoma humboldti en Schroederichthys chilensis (Chondrichthyes, Elasmobranchii, Scyliorhinidae) como indicador no destructivo de contaminación. Gayana (Conсерс) 69:160-165

Tantaleán M, Sánchez L, Gómez L, Huiza A (2005) Acantocéfalos del Perú. Rev Peruana Biol 12:83-92

> Tejeda-Vera R, López-López E, Sedeño-Díaz E (2007) Biomarkers and bioindicators of the health condition of Ameca splendens and Goodea atripinnis (Pisces: Goodeidae) in the Ameca River, Mexico. Environ Int 33:521-531

Van der Oost R, Beyer J, Vermeulen NPE (2003) Fish bioaccumulation and biomarkers in environmental risk assessment: a review. Environ Toxicol Pharmacol 13:57-149

Vidal-Martínez VM, Aguirre-Macedo ML, Scholz T, González-Solís D, Mendoza-Franco EF (2002) Atlas de los helmintos parásitos de cíclidos de México. CINVESTAVIPN, Mexico City

Voutilainen A, Figueiredo K, Huuskonen H (2008) Effects of the eye fluke Diplostomum spathaceum on the energetics and feeding of Artic charr Salvelinus alpinus. J Fish Biol 73:2228-2237

Submitted: August 18, 2009; Accepted: September 15, 2009 Proofs received from author(s): January 24, 2010 